\title{
Centres of Excellence in Teaching and Learning (CETL) as governing instruments in universities in England and Germany
}

\section{CHEPS WORKING PAPER 05/2015}

Katharina Lemmens-Krug, CHEPS (University of Twente), k.lemmens-krug@utwente,

Twitter: @KLemmensKrug

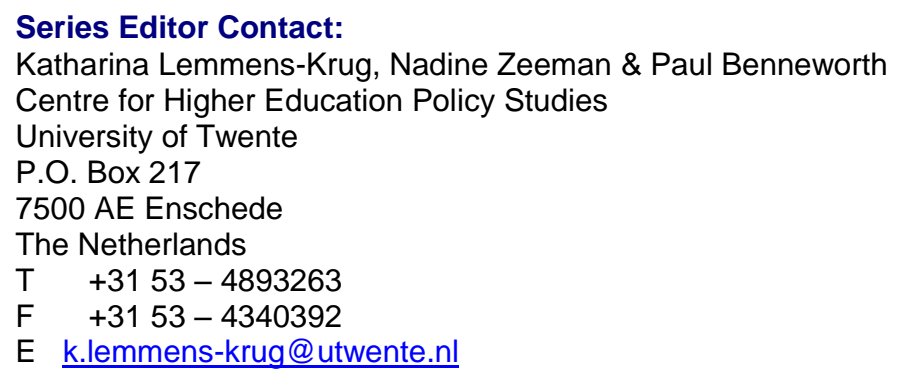




\section{Table of Contents}

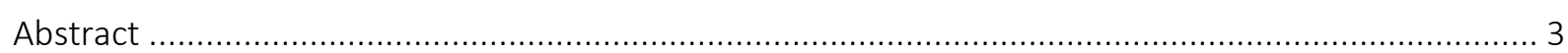

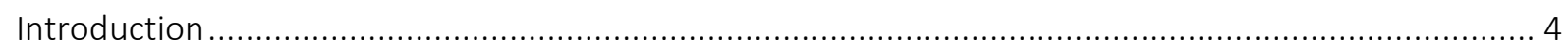

Shifts in Higher Education Governance - Towards Managerialism....................................................... 5

CETLS - Governing Instruments of Teaching and Learning in Universities ....................................... 9

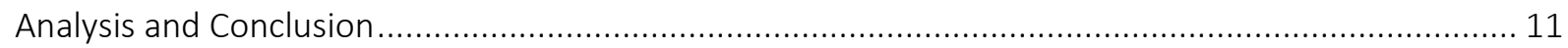

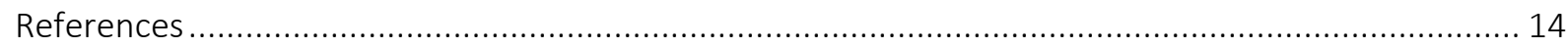




\begin{abstract}
There is little known about steering efforts by university leaders with regard to teaching and learning. In this conceptual paper the focus lies on Centres for Excellence in Teaching and Learning (CETLs) as an instrument of governance to steer teaching and learning activities in universities. The question how CETLs can be best understood as an instrument of governance in universities will be investigated. After having presented some 'managerialist' technologies of governing teaching and learning I will present two national initiatives that funded CETLs. The paper will draw on empirical examples of Germany and England in order to illustrate the governance instruments of CETLs. The paper concludes that on the conceptual level, managerialism can be one perspective to understand CETLs as a governing technology. It can be argued that CETLs inherit several features of managerialism, and therefore can be best understood as a managerialist technology in governing teaching and learning at universities.
\end{abstract}

Key words: Centres for Excellence in Teaching and Learning, steering in teaching and learning, university governance, managerialism 


\section{Introduction}

The governance concept is "ubiquitous", as explained by Bevir (2010a, p. 1) as he begins his overview on governance as theory, practice and dilemma in the Sage Handbook of Governance. The governance concept is indeed a well discussed concept, used in various theoretical perspectives and across the areas of politics, economics and society on all levels in academia as well as in practice. Its origin and its versatileness have been discussed elsewhere in detail (Bevir 2010b; Benz 2007; Levi-Faur 2012). How governance configurations in the policy arena of higher education are changing due to reforms in the past decades has been subject to many studies (as described in the literature review of the report on Governance and Funding Reform (Enders et al. 2008, p. 75)).

This conceptual paper discusses Centres for Excellence in Teaching and Learning (CETLs) as an instrument of governance to steer teaching and learning activities in universities. Wild (2012) identified two salient factors from studies on 'Professionalisation of higher education teaching and learning' for why steering efforts with regard to teaching and learning by university leadership remain limited. On the one hand, teaching and learning activities still lag in importance relative to research (Wild 2012, p. 192) and on the other hand the competencies for teaching and learning are typically decentralised and embedded in the faculties and at departments (Maassen et al. 2012, p. 1). In addition, teaching and learning are described as an "unclear technology", because they are complex processes and have an ambiguous causal relationship between what is taught and what the result - "the product" - actually is (Musselin 2007, p. 72). Musselin's (2007) insight underpins the relevance of inquiring into how and by which instruments teaching and learning is governed. The discussion on organisational units that support teaching and learning and quality improvement within universities such as CETLs is in fact addressing a phenomenon, on which little is known.

To understand this phenomenon the governance concept as developed by Mark Bevir and Clarke and Ozga (2011), will be used. An explanation of the governance concept is followed by a consideration of governance shifts in higher education. In a third step the instruments of governance that are inherent to the normative system of managerialism are discussed. Subsequently, I will analyse how CETLs can be best understood as governing instruments with regard to teaching and learning in higher education. 
Therefore I pose the question how CETLs can be best understood as an instrument of governance in universities? The paper will draw on empirical examples of Germany and England in order to illustrate the governance instruments of CETLs.

Bevir distinguishes a governance concept that applies to "phenomena that are hybrid, multijurisdictional with plural stakeholders who come together in networks" (Bevir 2010a, p. 2). By hybridity the mix of administrative systems with market mechanisms and non-profit organisations is meant. A combination of people and institutions across different policy sectors and different levels of government is what Bevir (2010a) describes as multijurisdictional.

The plurality of stakeholders in a policy area is also a distinct feature of the governance concept, or as Clarke and Ozga (2011, p. 2) put it: "governance is the co-production by many agents and agencies". Traditionally governance was seen as being exercised by one single entity, the state, whereas currently multiple stakeholders and agents are linked together in networks of governing arrangements and across different levels of governance. These new governing assemblages, a term coined by Clarke and Ozga, are fluid because the governing processes is open to change and the object of governance is constructed in the process of governing.

\section{Shifts in Higher Education Governance - Towards Managerialism}

Traditionally the quality of teaching and learning in higher education was something academics and teachers were primarily concerned with. Now a multitude of various stakeholders voice their ideas and thoughts about quality of teaching and learning (Westerheijden et al. 2007, p. 1). These stakeholders put forward varying concepts about the quality of teaching and learning in higher education. They demand, for example, that teaching and learning has to be internationally oriented, meet and implement European standards, meet the demands of labour markets as well as of students, academic staff and fee-paying parents. Besides students, labour markets, potential employers and parents, governmental authorities have an increased interest in the quality of teaching and learning.

Ministries and agencies at the national and international level primarily use quality assurance in higher education as a steering mechanism with regard to teaching and 
learning (Blackmur 2007, p. 15). Responsibilities in assuring quality have shifted in the past decades from a rather internal quality judgment to a process of external quality assurance done by quality assurance agencies (OECD 2003, p. 69). Moreover, in recent years the way in which universities are steered by the government and the way in which universities internally steer their teaching and learning processes and activities has changed. These changes are due to the diversified stakeholder demands in teaching and learning, or in other words the increasing plurality of stakeholders, and additionally due to a range of reforms to restructure higher education in western European countries.

These reforms have the aim of transforming the higher education sector to perform better (Würmseer 2010; Jongbloed 2009; Kloke and Krücken 2012).

Universities are granted increasing managerial autonomy by the state in order to manage their core activities in research, teaching and learning, and knowledge transfer (Kehm 2012, p. 18). By granting universities more managerial autonomy they are assumed to transform into 'organisation-like actors', which are more efficient and responsive to the needs of society. Universities deal with problems of public funding of mass higher education by being able to open up the HE system to third-party funding. Moreover, legitimacy issues and the lack of trust in quality higher education has led to financing higher education partly against measurable performance indicators. In addition to this profile-building and differentiation has gained importance. Finally, there are growing expectations with regard to the production of knowledge and its transfer into the public sphere (Kehm 2012, p. 18). This development can be summarised as decreasing state control while increasing the autonomy and competencies of the universities, specifically the university leadership in exchange for higher performance with regard to all spheres of the university: teaching and learning, research and knowledge transfer (Winde 2010, p. 5).

As a consequence of these higher education reforms, universities have more responsibility for their activities and are held accountable for their performance. Krücken (2011) and Meier (2009) argue that due to recent governance reforms of the higher education sector, the "university as an organization is transforming into an actor with distinct inherent properties this entails" (Krücken 2011, p. 4). These features are hierarchical decision-making, accountability, university-wide goals in form of a mission 
statement, differentiated organisational structure with offices and subdivisions for specialised tasks and the 'rise of the management profession' (Krücken 2011, p. 5).

The main logic driving governance changes in higher education is assumed to be "managerialism", as has been claimed by many scholars in the area of New Public Management of higher education (Hood 1991; Boer et al. 2007a; Boer et al. 2007b; Birnbaum 2000). Ozga (2015, p. 8) suggests that "managerialism is a normative belief system, which legitimises particular versions of 'how to manage'”. Managerialism is an umbrella concept for understanding cultural, institutional and organisational changes, specifically the shift in behaviours, expectations, values and beliefs brought about by the importation of business rationalities and practices into the public sector (Duggan 2014, p. 22).

Managerialist ideas originate from the private sector. The term "new managerialism" emerged in the late $90 \mathrm{~s}$ because managerialist organisational forms, technologies and management practices were adopted by public sector organisations (Deem 1998). The significance of managerialism can be understood by the combination of translation and assemblage as Clarke et al. (2015, p. 101) outlines. The former means that managerialism has the capacity to move across places and settings, because the managerial "wisdom and authority" are universally applicable. The latter - assemblages of power - means that managerialism carries the "promise of reorganising established formations of power and authority" and bring about "innovation, dynamism and efficiency" (Clarke et al. 2015, p. 101). The core features attributed to managerialism are: innovativeness, external-orientation, customer-centredness, transparency, performance-centredness and result-orientation (Ozga 2015b, p. 9). Translated to the university this means a change towards internal cost centres, incentivising competition between employees, the marketisation of university services and the monitoring of efficiency and effectiveness through measuring the outcomes and performances of the academics (Deem 1998, p. 50).

Lascoumes and Le Gales (2007) argue that policy instruments are not neutral devices as they produce specific effects independently of the objective that is pursued.

Furthermore, every instrument constitutes a condensed form of knowledge about social control and ways of exercising it (Lascoumes, Pierre and Le Gales, Patrick 2007, p. 11). Within managerialism particular practices and technologies are used for governing, 
which are legitimised by the normative belief system of managerialism. Examples of these technologies include the use of data and comparisons based on indicators and benchmarks. The knowledge that is drawn from these comparisons is used to derive policy actions and 'best practice' solutions (Fenwick et al. 2014, p. 3). The technologies employed enable goal-governed steering of outputs and outcomes (Ozga 2015c, p. 2).

Managerialist technologies inherit the features attributed to managerialism, which legitimise a particular version of "how to manage". The technologies are 'propagated' as being innovative, efficient and effective, user-driven/customer focussed (Ozga 2015d, p. 17). Therefore, it can be assumed that CETLs as a governing instrument to enhance the quality of teaching and learning in higher education institutions are also constituted by a particular form of social control and ways how this control is exercised. Which particular form of social control and which ways of control will be analysed at in the third section of the paper.

From the literature we know of several technologies and policy instruments with regard to governing teaching and learning in universities. In the area of governing research in universities use of managerial technologies might be obvious, such as the focus on research output which is measured against various indicators such as the number of publications or the h-index. In the area of teaching and learning there are also certain technologies that inherit managerial features. Examples are qualification frameworks and learning outcomes, because these technologies create transparency and make universities more efficient organisations by using standardisation which are built on managerial logics (Pettersen 2015, p. 23). In fact, through student learning outcomes are measurable products focussed on performativity (Deem 1998, p. 53). Furthermore, the modularisation and introduction of credit frameworks can be seen as a managerialist technology, because they carry elements of economy and efficiency, as well as potential for market responsiveness and income generation. Its ability to extend managerial surveillance and control and its ideological and discursive symmetry was analysed by Trowler (1998, p. 95). Having briefly presented some managerialist technologies of governing teaching and learning I will now introduce the national initiatives that funded CETLs in England and Germany. 


\section{CETLS - Governing Instruments of Teaching and Learning in}

\section{Universities}

CETLs are aimed at enhancing the quality of teaching and learning and thereby pursue excellence in teaching and learning within their university, as indicated by their name. Readings (1996) argues that the discourse of excellence replaces the ideology of the (national) culture. In fact, he claims that the decline of the national culture, which has up to now provided a raison d'être to the university is replaced by the European Union (EU) with the idea of separating the university from the nation-state (Readings 1996, p. 3). The 'strategic goal' of the EU of becoming "the most competitive and dynamic knowledge-based economy in the world capable of sustainable economic growth with more and better jobs and greater social cohesion" was clearly stated in the Lisbon Strategy (European Council 2000). Higher education with its core activities of educating, researching and innovating plays an integral role in the knowledge-based economy and society. The European Union further concludes that the higher education sector should "therefore pursue excellence and become a world-wide quality reference" (Council of the European Union 2004, p. 12).

The increased 'assumed importance' that quality of teaching and learning and the pursuit of excellence has received in recent years can be further exemplified by the debates and initiatives at the European, national and institutional levels. At the European Union level the Modernisation Agenda of Higher Education (COM/2011/0567 final) set the goal of improving the quality and relevance of teaching and learning by a range of activities like mandating a High-level Group on the modernisation of higher education. This group is employed to produce key recommendations with regard to the quality of teaching and learning. Furthermore, the group promotes European cooperation in quality assurance in higher education and the European Standards and Guidelines for Quality Assurance (European Commission 2015). Additionally the OECD has studied effective quality teaching initiatives and promoted institutional practices to stimulate peer learning, with its project called 'Supporting Quality Teaching in Higher Education' and UNESCO emphasises in its mission statement that it 'contributes to enhancing quality education' (UNESCO 2014). Not least, the Bologna reforms, that transformed the traditional degree structure to a bachelor-master structure, shifted the 
public focus to teaching and learning activities at universities and how universities are steered and organised (Wild, Harde, Maria, H. 2008, p. 99)

Several changes have been initiated within universities as a consequence of that attention, such as the implementation of Centres for Excellence in Teaching and Learning, which were funded on the national level in order to enhance the quality of teaching and learning. In Germany, the "Quality Pact for Teaching” programme (Qualitätspakt Lehre) aims to improve the study conditions, the quality of teaching and mentoring in higher education by funding relevant initiatives at higher education institutions. The funding scheme is a joint programme of the German Federal Ministry of Education and Research (BMBF) and the federal states (Bundesministerium für Bildung und Forschung 2011).

Higher education institutions compete for funding with a concept they developed of an (institution-wide) approach for enhancing the study conditions and/or the quality of teaching and/or the mentoring for students. Therefore, the institutions had the freedom to develop distinctive initiatives for their institutional context. The range of concepts involved, among other things, the employment of more university teachers, the implementation of new didactical methods, the use of e-learning methods, the professionalisation of university teachers as well as the creation of new organisational units offering study-related counselling and mentoring for students and teachers alike (Kottmann, Andrea and Lemmens-Krug, Katharina 2014).

In total 186 higher education institutions receive funding from the 'Quality Pact for Teaching' programme, including 78 universities, 78 universities of applied science and 30 colleges of art and music. For this initiative about 2 billion euros are to be spent between 2011 and 2020. In 2016 a mid-term review of all funded projects will take place in order to determine if they are eligible for further funding until 2020 (Bundesministerium für Bildung und Forschung 2011).

In the United Kingdom (UK), the Higher Education Funding Council for England (HEFCE) initiated Centres for Excellence in Teaching and Learning to enhance the status of learning and teaching in higher education (HEFCE 2011). The funding of CETLs is in line with the reform efforts to provide students with courses of enhanced quality and better qualified teachers (Department for Business, Innovation \& Skills 2010, p. 47). The White 
Paper of the ministerial department for education has set the frame for the CETL programme by announcing that reform efforts included "Centres of Excellence to reward good teaching and promote best practice" (Department for Education and Skills 2003, p. 7).

The UK CETL programme was the largest ever single funding initiative in teaching and learning in England with a budget of 315 million pounds for a period of 5 years between 2005 and 2010 (SQW 2011, p. 1). Out of 106 bids for establishing CETLs 74 were awarded with funding from 2005 onwards. The diversity of CETLs that have been funded is vast in size, scale (single institution or collaborations), single-disciplinary and/or multi-disciplinary focus, pedagogic spread, regional and institutional spread (SQW 2011, p. 8). With regard to the embeddedness of the CETL in the university and the structure of the CETL, three different categories have been identified by SQW (2011, p. 9): 1) stand-alone CETLs, 2) CETLs based within, or closely linked to, an existing central support unit, 3) CETLs based within a single department or faculty, or across more than one faculty.

\section{Analysis and Conclusion}

Having outlined the national initiatives I will analyse the CETLs on a conceptual level, drawing on the information about the objectives, structures and activities of CETLs in the UK and Germany. CETLs can be treated as an institutional governing instrument, which are employed by the university leadership to bring about change within the university with regard to teaching and learning. The concept of a "Centre of Excellence" comes from the private sector, to be precise from multinational companies (Mieg 2014, p. 71). The definition used for a centre of excellence is "an organizational unit that embodies a set of capabilities that has been explicitly recognized by the firm as an important source of value creation, with the intention that these capabilities be leveraged by and/or disseminated to other parts of the firm" (Frost et al. 2002, p. 997). Centres of excellence can be distinguished in three types, ranging from a centre that embodies a particular competence in a company, to a centre of excellence that is recognised by the company and lastly a centre of excellence that serves a specific function within the company (Mieg 2014, p. 72). 
CETLs are in most cases located at the central university level. They are implemented by the university leadership, from which they receive their right to exist and the mandate to act as agents of change (Gosling, Turner 2015, p. 10). The university leadership together with the CETLs attempts to steer the behaviour of academic teachers in order to develop their academic practices and enhance their teaching methods. Thereby they draw on different kinds of authority, both the formal authority and informal authority. By the former I mean the structural regulations the university leadership has at its disposal in order to steer and control the behaviour of academic teachers. By informal authority I mean the expert knowledge that is concentrated in a CETL, which is based on the several activities that take place in a CETL. These are: 1) conducting research on teaching and learning methods 2) providing services to students (mentoring and counselling) and academics (training and career development) 3) the involvement in the general organisation of teaching and learning processes, which are amongst other things quality assurance and enhancement. Every CETL is unique - they differ in their structure, their maturity and in the variety of tasks they do.

With the implementation of a CETL, the knowledge about teaching and learning methods, activities and processes are concentrated at the CETL at the central level, whereas traditionally the competencies for teaching and learning were decentralised and the knowledge was embedded in the faculties and at departments (Maassen et al. 2012, p. 1). The idea that the CETL can provide services to all academic teachers, independently of their discipline, has its roots in the notion that the knowledge on teaching and learning concentrated in the CETL is universally applicable. Moreover, the university leadership by implementing a CETL is promoting the CETL as the "bearer of relevant knowledge and expertise" (Clarke 2009, p. 35) on teaching and learning and thereby devaluing the knowledge on teaching and learning which is embedded in the faculties, more specifically the knowledge and expertise of the academic teachers. The knowledge and expertise of the CETL is de-contextualised, because it is not anymore linked to the discipline, but promotes general knowledge that can travel across the contexts. This notion of de-contextualised knowledge, borrowed from Grundmann, Stehr (2012, p. 3), might promote the standardisation of teaching practices.

The de-contextualisation of knowledge and expertise through CETLs cannot only be considered with regard to the disciplinary roots, in which teaching and learning 
traditionally took place. There is more to it - namely that excellence has no content on its own (Readings 1996, p. 2), it is not "a fixed standard of judgment but a qualifier whose meaning is fixed in relation to something else" (Readings 1996, p. 24). Excellence therefore allows for diversity and plurality of views on what excellent teaching actually is. This element has again the notion of consumer-orientation, because by pursuing excellence the university caters for the many and diverse needs of the "consumers", consisting of the academic teachers from several disciplines, a heterogeneous student population, the labour market, potential employers, fee-paying parents, the governmental authorities, and quality agencies. Excellence, as Readings argues, facilitates an understanding of the university solely in terms of the structure and corporate administration (1996, p. 29), conversely to the understanding which is based on the (national) culture (1996, p. 2). It can be assumed that CETLs are sponsoring the development of the university to transform "itself from an ideological arm of the state into a bureaucratically organized and relatively autonomous consumer-oriented corporation" (Readings 1996, p. 11).

There are more features of CETLs that can be linked to managerialism. CETLs are promoting their services within the university, as 'change agents' they are assumed to be dynamic and innovative. The notion that CETLs provide services within the university with regard to teaching and learning very clearly points into their customer-centred nature. The customers being on the one hand the academic teachers that receive training and career development advise and on the other hand the students that receive mentoring and counselling. In addition, by implementing a CETL, the idea that an organisational unit is better equipped and more efficient - than decentralised efforts in enhancing the quality of teaching and learning is promoted. Also, the knowledge and expertise that is concentrated at the CETL is more transparent than the knowledge on teaching and learning that was embedded in the faculties. Through their activities and the knowledge on teaching and learning that is produced in the CETL, they actively shape the actors practices and knowledge and thereby operate as a governing technology.

On the conceptual level, managerialism can be one perspective to understand CETLs as a governing technology. It can be argued that CETLs inherit several features of managerialism, and therefore can be best understood as a managerialist technology in 
governing teaching and learning at universities. However, as the evaluation of the CETL programme in the UK concludes there is a 'delicate balance' to be struck between longestablished tradition of the academic autonomy and more centralised management of initiatives" like CETLs (SQW 2011, p. 6). Gosling, Turner (2015) identified three areas of contestation in their study, firstly pedagogy being about the contradictory assumptions about teaching and learning, like the role of the students, reconceptualisation of teaching space and the use of technologies. Secondly, the organisational culture of several faculties, like the forms of networks, ways of working, and the relation between teaching and research. Thirdly, the epistemology, meaning the conflicting assumptions about the discipline, curriculum content, the kind of knowledge and the forms of knowledge creation (Gosling, Turner 2015, p. 12). All three areas of contestation can be linked back to the traditional embeddedness of teaching and learning in the disciplines, from which contesting practices with regard to pedagogy, organisational cultures and epistemology evolved. Thus, it could be argued that the disciplinary embeddedness of teaching and learning is an alternative form of social control in contrast to managerialism.

Based on the conceptual analysis of CETLs as a governing technology in this paper, an interesting avenue for further research would be to empirical investigate the assumptions of managerialist features in Centres for Excellence in Teaching and Learning to better understand their governing rationale.

\section{References}

Benz, Arthur (Ed.) (2007): Handbuch Governance. Theoretische Grundlagen und empirische Anwendungsfelder. 1st ed. Wiesbaden: Verlag für Sozialwissenschaften.

Bevir, Mark (2010a): Governance as Theory, Practice, and Dielmma. In Mark Bevir (Ed.): The SAGE Handbook of Governance. London: Sage Publications, pp. 1-16.

Bevir, Mark (Ed.) (2010b): The SAGE Handbook of Governance. London: Sage Publications.

Birnbaum, Robert (2000): Management fads in higher education. Where they come from, what they do, why they fail. San Francisco: Jossey-Bass.

Boer, Harry de; Enders, Jürgen; Leišyte, Liudvika (2007a): Public Sector Reform in Dutch Higher Education. The Organizational Transformation of the University. In Public Administration 85 (1), pp. 27-46. DOI: 10.1111/j.1467-9299.2007.00632.x.

Boer, Harry de; Enders, Jürgen; Schimank, Uwe (2007b): On the Way Towards New Public Management? The Governance of University Systems in England, the Netherlands, Austria, and Germany. In Dorothea Jansen (Ed.): New forms of governance in research organizations. Disciplinary approaches, interfaces and integration. Dordrecht: Springer, pp. 135-152.

Bundesministerium für Bildung und Forschung (2011): Political objective. Available online at http://www.qualitaetspakt-lehre.de/en/1294.php, checked on 9/26/2015.

Clarke, John (2009): Governance puzzles. In Leslie Budd, Lisa Harris (Eds.): e-Governance. Managing or governing? New York, NY: Routledge (Routledge e-business series), pp. 29-52. 
Clarke, John; Bainton, David; Lendvai, Noémi; Stubbs, Paul (Eds.) (2015): Making policy move. Towards a politics of translation and assemblage / John Clarke, David Bainton, Noémi Lendvai and Paul Stubbs. Bristol: Policy Press, University of Bristl.

Clarke, John; Ozga, Jenny (2011): A Note on Governing. Inspection as Governing. Department of Education, University of Oxford. Oxford. Available online at www.education.ox.ac.uk/wordpress/wp-content/uploads/2013/10/WP-4-Inspection-asGoverning.doc, checked on 9/22/2015.

Council of the European Union (2004): “Education \& Training 2010" The Success of the Lisbon Strategy Hinges on Urgent Reforms. Joint in-terim report of the Council and the Commission on the implementation of the detailed work programme on the follow-up of the objectives of education and training systems in Europe. COM (2003) 685 final. Brussels.

Deem, Rosemary (1998): 'New Managerialism' and Higher Education: the management of performances and cultures in universities in the United Kingdom. In International Studies in Sociology of Education 8 (1), pp. 47-70.

Department for Business, Innovation \& Skills (2010): The Browne report: higher education funding and student finance. Available online at https://www.gov.uk/government/publications/the-browne-report-higher-educationfunding-and-student-finance.

Department for Education and Skills (2003): The future of higher education. Edited by Crown Copyright. London.

Duggan, James R. (2014): Embedded Research: Contextualizing Managerialization in a Local Authority. In Helen M. Gunter, Dave Hall, Colin Mills (Eds.): Education Policy Research. Design and practice at a time of rapid reform. New York: Bloomsbury Academic (Bloomsbury Research Methods), pp. 17-30.

Enders, Jürgen; File, Jon; Boer, Harry de; Babyesiza, Akiiki; Kaiser, Frans; Kehm, Barbara et al. (2008): Progress in higher education reform across Europe. Governance and Funding Reform.

European Commission (2015): Quality and Relevance in Higher Education. Available online at http://ec.europa.eu/education/policy/higher-education/quality-relevance_en.htm, checked on $9 / 18 / 2015$.

European Council (2000): Lisbon European Council Presidency Conclusions. European Council. Lisbon. Available online at http://www.europarl.europa.eu/summits/lis1_en.htm, checked on $9 / 26 / 2015$.

Fenwick, Tara J.; Mangez, Éric; Ozga, Jennifer (2014): Comparison, Knowledge-Based Technologies and Expertise in the Regulation of Education. In Tara J. Fenwick, Éric Mangez, Jennifer Ozga (Eds.): Governing knowledge. Comparison, knowledge-based technologies and expertise in the regulation of education. London: Routledge/Taylor and Francis Group (World yearbook of education, 2014), pp. 3-10.

Frost, Tony S.; Birkinshaw, Julian M.; Ensign, Prescott C. (2002): Centers of excellence in multinational corporations. In Strat. Mgmt. J. 23 (11), pp. 997-1018. DOI: 10.1002/smj.273.

Gosling, David; Turner, Rebecca (2015): Responding to contestation in teaching and learning projects in the Centres for Excellence in Teaching and Learning in the United Kingdom. In Studies in Higher Education, pp. 1-15. DOI: 10.1080/03075079.2014.899339.

Grundmann, Reiner; Stehr, Nico (2012): The power of scientific knowledge. From research to public policy. New York: Cambridge University Press.HEFCE (2011): Summative evaluation of the CETL programme. Higher Education Funding Council for England. Available online at http://www.hefce.ac.uk/pubs/rereports/Year/2011/cetlsummevaln/Title,92265,en.html , checked on 3/23/2015.

Hood, Christopher (1991): A Public Management For All Seasons? Hood, Christopher. In Public Administration 69 (1), pp. 3-19. DOI: 10.1111/j.1467-9299.1991.tb00779.x.

Kehm, Barbara (2012): Hochschulen als besondere und unvollständige Organisationen? - Neue Theorien zur 'Organisation Hochschule. In Uwe Wilkesmann, Schmid, Christian, J. (Eds.): Hochschule als Organisation. Wiesbaden: Springer VS (Organisationssoziologie), pp. 17-25.

Kottmann, Andrea and Lemmens-Krug, Katharina (2014): CETLFUNK. Available online at https://www.utwente.nl/bms/cheps/cetlfunk/, checked on 9/26/2015. 
Krücken, Georg (2011): A European Perspective on new Modes of University Governance and Actorhood. International Center for Higher Education Research (INCHER). Berkeley

(Research \& Occasional Paper Series: CSHE, 17). Available online at http://www.cshe.berkeley.edu/sites/default/files/shared/publications/docs/ROPS.Kruecke n.EuroView.12.13.11.pdf , checked on 7/15/2015

Lascoumes, Pierre and Le Gales, Patrick (2007): Introduction: Understanding Public Policy through Its Istruments - From the Nature of Instruments to the Sociology of Public Policy Instrumentation. In Governance: An International Journal of Policy, Administration, and Institutions 20 (1), pp. 1-21.

Levi-Faur, David (2012): Oxford handbook of governance. Oxford: Oxford University Press ([Oxford handbooks]).

Maassen, Peter; Nerland, Monika; Pinheiro, Rómulo; Stensaker, Bjørn; Vabø, Agnete; Vukasović, Martina (2012): Change Dynamics and Higher Education Reforms. In Martina Vukasović, Peter Maassen, Monika Nerland, Rómulo Pinheiro, Bjørn Stensaker, Agnete Vabø (Eds.): Effects of Higher Education Reforms: Change Dynamics. Rotterdam: SensePublishers (Higher Education Research in the 21st Century Series, 4), pp. 1-16.

Meier, Frank (2009): Die Universität als Akteur. Zum institutionellen Wandel der Hochschulorganisation. Wiesbaden: VS Verlag für Sozialwissenschaften / GWV Fachverlage $\mathrm{GmbH}$, Wiesbaden (Organisation \& public management).

Mieg, Harald (2014): The Organisational Embedding Of Expertise: Centres of Excellence. In Talent Development \& Excellence 6 (71-93).

Musselin, Christine (2007): Are universities specific organisations?, pp. 63-84.

Ozga, Jenny (2015a): Governing Education in Europe: From partnership to privatisation. Lecture 1: Education as Field of Study and as a Policy Field. Oslo.

Ozga, Jenny (2015b): Governing Education in Europe: From partnership to privatisation. Lecture 3: The Modernizing State: education, economy and citizenship. Oslo.

Ozga, Jenny (2015c): Governing Education in Europe: From partnership to privatisation. Lecture 5: Governing by Numbers: the rise of data. Oslo.

Ozga, Jenny (2015d): Governing Education in Europe: From partnership to privatisation. Lecture 7: Governing the Academy: changing knowledge production? Oslo.

Pettersen, Inger Johanne (2015): From Metrics to Knowledge? Quality Assessment in Higher Education. In Financial Accountability \& Management 31 (1), pp. 23-40.

Readings, Bill (1996): The university in ruins. Cambridge, Mass.: Harvard University Press.

SQW (2011): Summative evaluation of the CETL programme. Final report by SQW to HEFCE and DEL.

Trowler, Paul (1998): What managerialists Forget. Higher education credit frameworks and managerialist ideology. In International Studies in Sociology of Education 8 (1), pp. 91-110. DOI: $10.1080 / 0962021980020020$.

UNESCO (2014): Mission and Strategy. United Nations Educational, Scientific and Cultural Organization. Available online at http://www.unesco.org/new/en/education/themes/strengthening-educationsystems/higher-education/mission/ , checked on 9/18/2015.

Wild, Elke; Harde, Maria, H. (2008): Hochschulen im Wandel - Perspektiven für eine interdisziplinäre Hochschulforschung. In Marion Kamphans, Sigrid Metz-Göckel, Karin Zimmermann (Eds.): Perspektiven der Hochschulforschung. 1st ed. Wiesbaden: VS Verlag für Sozialwissenschaften, pp. 97-111.

Winde, Mathias (2010): Von der Qualitätsmessung zum Qualitätsmangement. Praxisbeispiele an Hochschulen. Essen: Ed. Stifterverband (Positionen). 
The Center for Higher Education Policy Studies (CHEPS) is a research institute (WHW, Article 9.20) located in the Faculty of Behavioural and Management Sciences within the University of Twente, a public university established by the Dutch government in 1961. CHEPS is a specialized higher education policy centre that combines basic and applied research with education, training and consultancy activities. 